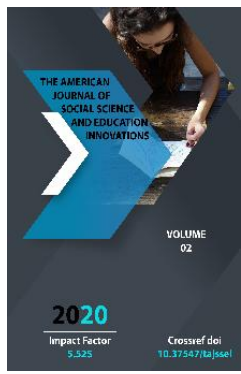

\title{
On The Issues Of Patriotic Education Of Youth And Military Services In Uzbekistan
}

Adolat Yakhyaeva

Independent researcher, Tashkent State Pedagogical University named after Nizami, Uzbekistan

Copyright: Original content from this work may be used under the terms of the creative commons attributes 4.0 licence.

\section{ABSTRACT}

The article reflects the problems and experiences of the first years of independence of the Republic of Uzbekistan in preparing young people for the call and patriotic education. Information is provided on the specifics of military service and the conditions created in the country for military service.

\section{KEYWORDS}

Military service, patriotism, Armed Forces, defense, military personnel.

\section{INTRODUCTION}

The object of patriotic education in any society is the youth and children. The upbringing of the younger generation in the spirit of patriotism is a very complex process, which must be carried out on the basis of a well-structured system of education, because patriotism is formed in a specific environment, on the ground and on the basis of existing spiritual and moral values.

It is no secret that "national spirituality" was discriminated against in all respects during the years of oppression and subjugated to a solitary ruling ideology far removed from nationalism. The former Soviet Union viewed the Uzbek people's understanding of its spirituality and its implementation as detrimental to the communist ideology, as its spirituality aspired to the whole nation, its faith as an idol, which frightened the former center and frightened the self-conscious people to strive for independence. 


\section{THE MAIN RESULTS AND FINDINGS}

In the former Soviet Union, patriotic education had no place in the educational system at all. The attitude to the concept of homeland was aimed at the formation of international unity. Z.M. Islamov wrote about this: "The term" country "has never been used by the Red Empire in relation to Uzbekistan. At the time, the very popular phrase: "My address is nor street or house, my address is the Soviet Union" was based on a very insidious policy. The level of patriotic and spiritual-moral education of the youth brought up on the basis of this idea was also aimed at homelessness and the complete removal of the feeling of patriotism from the hearts of young people.

Patriotic education is formed on the basis of the concepts of "Vatan tuygusi"(The feeling of Homeland), "Ona Vatan"(Mother Land). Therefore, this education is effective when it is carried out through the joint efforts of all state and public organizations. At the heart of patriotism are love for the motherland, protection of the homeland from the enemy, liberation from any dependence, and not sacrificing one's life for freedom and independence. Therefore, these cases were manifested even in emergencies that required self-sacrifice in the long military service for the defense of the Motherland.

The First President of Uzbekistan I.Karimov described the people who sacrificed their lives for the sacred duty of defending the Motherland as "Defenders of the Motherland" : brave and courageous boys who are passionate, have modern military knowledge and skills, and are ready for any courage in the way of such a noble goal as maintaining peace and stability.

From the first days of independence, the Republic of Uzbekistan has paid great attention to the personnel of the Armed Forces to be informed about the national traditions, history, culture and the role of the army in society. The naming of the former DOSAAF as "Patriot" at the November 23, 1991 congress, and the renaming of the newspaper "Frunzevets" of the former Turkestan military district "Patriot" played a unique role in instilling patriotism in young people, fully understanding the essence of patriotism. Since 1992, in order to form the morale of servicemen, "Social and humanitarian training" trainings have been introduced. Until now, the subject of "Marxist-Leninist training" conducted with servicemen has been removed from the curriculum. This, in turn, created a unique nationalism in the training of military personnel, the formation of national statehood. Socio-humanitarian training plays an important role in educating servicemen about the structure of the country and its rich history, the development of socio-political, cultural and educational ties of the people of Uzbekistan, educating military personnel in the spirit of patriotism. "The program of social humanitarian training " for officers of the personnel is set at 120 hours, for ordinary soldiers - 108 hours. These classes have been called "Socio-political training" since 1999 and "Spiritual and educational training" since 2009.

According to the Instruction of the Minister of Defense of Uzbekistan dated April 10, 2003 "On the organization of socio-political training in military units and institutions of the Ministry of Defense" to explain to the personnel the rich history, spiritual heritage, the idea and ideology of national independence, current issues of domestic and foreign policy, defense, military construction.

After the establishment of the Ministry of Defense of Uzbekistan, in 1992, the responsibilities of young people and servicemen in the field of patriotic education were further expanded. The Law of the Republic of Uzbekistan "On conscription and military service" was adopted. This law is the main law that unifies the activities of the 
Central Committee "Vatanparvar", which covers all issues related to the "preparation of citizens for military service."

According to this law, the preparation of conscripts and conscripts for military service in Uzbekistan was as follows:

1) pre-conscription training of juveniles;

2) training of conscripts in military equipment;

3) preparation for admission to military educational institutions and physical training.

4) medical treatment;

5) raising the level of general education;

6) teaching the state language;

7) upbringing in the spirit of patriotism.

Thus, in order to improve the system of spiritual, moral and patriotic education of young people and servicemen in the system of the Ministry of Defense of Uzbekistan, cooperation has been established with state and public organizations.

Another important vital factor that directly affects the formation of spirituality is that education is closely linked to the educational system. It is known that our ancestors from ancient times considered science, enlightenment, education and upbringing, which are invaluable resources, as the main condition and guarantee of human perfection and development of the nation. To know the past is to understand the future. In this regard, the study and re-examination of martial arts in our Armed Forces remains an important part of all our work today to modernize our army. From the first days of independence, special attention was paid to the teaching of philosophy, law, history, ethics, religion, and the provision of libraries with art and scientific literature, which played an important role in the spiritual formation of cadets in higher military education.
Regular creative meetings of servicemen and their families with prominent figures of science and culture of the country, as well as evenings dedicated to specific topics by the Center for Spirituality and Enlightenment of the Ministry of Defense also helped to create a sense of homeland among servicemen. The Republican Center for Spirituality and Enlightenment, "Kamolot" Youth Social Movement, "Makhalla", "Nuroniy" Foundations, "Women's Committee" and their local branches have been cooperating in organizing such events in the military districts of the Armed Forces. This is evidenced by the competitions "The most exemplary family", "Exemplary young military family", which have been held regularly since 2003 in cooperation with public organizations on the scale of military units, institutions, districts and the Armed Forces. One of the factors in raising a person's spirituality is the family, because the more a healthy environment is established in the family, the longer the future of the young people raised in this family will last.

The First President of the Republic of Uzbekistan, Supreme Commander-in-Chief of the Armed Forces I.Karimov at the opening ceremony of the Oath of Allegiance monument on January 12, 2010 in Tashkent emphasizing the role and importance of spiritual preparation.

The Republic of Uzbekistan considers that the defense of the Motherland is the duty of all citizens, as well as the duty of military personnel of the Armed Forces, in which servicemen must use all their strength, knowledge, skills, experience and, if necessary, be ready to sacrifice their lives. At the same time, from the first days of independence, history has shown that the spirituality of all its citizens and the formation of a patriotic personality is one of the most important tasks for Uzbekistan. In other words, we need to bring up a well-rounded, healthy generation that recognizes their rights, relies on their own strengths and 
capabilities, and most importantly, all young people who have served in the military and the army to defend the country as well as they need to grow up to be trustworthy people who have clearly defined their place.

Prior to independence, Uzbekistan took and should have taken measures aimed at strengthening the military service and the education of young people, their worldview, especially in the field of patriotism. The reason was that most of the young people brought up under the communist ideology at that time looked to the future with uncertainty and an ideological gap appeared in their minds.

In the history of the Armed Forces of Uzbekistan, the role of state policy in the formation of the morale of servicemen is enormous, and this task is carried out by the leadership of the state, understanding the simple fact that enlightenment and culture develop. This, in turn, has made it possible to solve even the most complex problems facing the country.

The military-patriotic events held by the "Kamolot" Youth Foundation of Uzbekistan, "Vatanparvar" Defense Assistance Organization, "Makhalla", "Nuroniy", "Soglom Avlod" non-governmental non-profit organizations have become an important factor in creating the necessary environment and conditions for strengthening the spiritual and moral education of the country's youth. This is confirmed by many archival materials and literature published during the independence period. In this regard, the Chairman of the Board of the Youth Foundation of the Republic of Uzbekistan "Kamolot" H.M.Abduraimov conditionally divides the work on military patriotism during the independence into 3 major areas. The first showed the work done to prepare students for military service and enrollment in higher military education, the second the work with soldiers and young officers, the third the work on the development of military-technical sports.

A serviceman standing in the defense of the country must be a devotee of his profession. Devotion is the main sign of patriotism, and the spirituality of a patriotic person is high. January 14 was declared the Day of Defenders of the Motherland by the Law of the Republic of Uzbekistan on December 29, 1993, and its inclusion in the list of public holidays has once again raised the level of respect and esteem for the Defenders of the Fatherland in the country.

"... January 14," writes the First President of the Republic of Uzbekistan I.A. Karimov, describing the holiday "Defenders of the Motherland", - not only servicemen, but also thousands of our compatriots who have served in the army and thousands who will serve tomorrow. We must accept it as a holiday of our young children, and celebrate it on a high level, like the great and dearest holiday - Independence Day".

\section{CONCLUSION}

In conclusion, it can be said that the highspirited serviceman is vigilant on the borders of the country, protects our independence, peace and tranquility, strengthens the defense potential of Uzbekistan, and the people of Uzbekistan are proud of having a powerful Armed Forces.

\section{REFERENCES}

1. Islomov Z.M. Uzbekistan towards modernization and democratic development. - T .: “Uzbekistan” 2005. B19.

2. Karimov I. Holiday greetings to the defenders of the Motherland.// People's speech. January

3. Bulletin of the Supreme Council of the Republic of Uzbekistan. № 10 (1198) pp37-40. 
4. Bulletin of the Supreme Council of the Republic of Uzbekistan. № 10 (1198) B-37.

5. Karimov I.A. High spirituality is an invincible force., Tashkent, "Spirituality", 2008. Pp. 60-61.

6. Karimov I.A. Holiday greetings to the defenders of the Motherland // Vatanparvar, 2010, January 15.

7. Xojimuratov G. Homeland begins with the family. // Vatanparvar, 2010y. March 26.

8. Information bulletin.T : № 14.1999. Pp.62-67.

9. The truth of Tashkent // January 14, 1994. 2 pages.
10. Omonov, Q., \& Karimov, N. (2020). Importance Of Ancestoral Heritage. The American Journal of Social Science and Education Innovations, 2(09), 196-202.

11. Karimov, N. R. (2020). A True Successor of Great Central Asian Scholars. Journal «Bulletin Social-Economic and Humanitarian Research,(7), 62-69. 